\title{
Development of Variations of Complete Learning to Develop Basic Jumping Ability and Character-Based Value Approach to Play for Class 4 Elementary School Students
}

\author{
$1^{\text {st }}$ Doris Apriani Ritonga ${ }^{1}, 2^{\text {nd }}$ Suryadi Damanik ${ }^{2}, 3^{\text {rd }}$ Iwan Saputra $^{3}$ \\ \{dorisritonga@unimed.ac.id ${ }^{1}$, suryadi67@gmail.com², Siwan9439@gmail.com³ \\ Faculty of Sports Science, Universitas Negeri Medan, Indonesia ${ }^{1,2,3}$
}

\begin{abstract}
One of the very basic weaknesses is the low creativity and innovation of teachers in developing basic movement skills and character values with a play approach, in this case playing is made in the form of games that suit the needs of students. Teachers tend to use existing forms of games such as baseball, soccer, volleyball and basketball, even though these games are basically not in accordance with the growth and development level of elementary school children. This study aims to develop a variety of physical education learning in sports and health based on a play approach. The research method used is Sugiono research and development. The research subjects were 4th grade elementary school students and 4 teachers at UPT Percut Sei Tuan. So that the variation of physical education learning based on the play approach is suitable for improving basic techniques and character values for elementary school students.
\end{abstract}

Keywords: jumping ability, ariations, approach to play.

\section{Introduction}

Physical sports and health education (PJOK) taught in schools provides opportunities for students to be directly involved in various learning experiences through selected physical activities, sports, and health that are carried out systematically. Good physical education must be able to increase and develop children's knowledge of basic movement principles, and character values.

Government policies through the Ministry of Education and Culture regarding character education in the 2013 Curriculum need to be welcomed and supported by all parties. Character education is not only important but absolutely must be done by every nation if it wants to become a civilized nation. Many facts prove that advanced nations are not caused by the nation having abundant natural resources, but a nation that has superior characters such as honesty, hard work, responsibility, spotivity, discipline, and others.

The development of science, technology, communication, and the flow of globalization has brought about changes in various aspects of life, including in the field of education. The home/family environment, which should be an educational institution, does not play a role in building children's character. Parents are busier with their own business, so there is no time to interact and educate their children. As a result, children are educated more by television and internet shows that are not in accordance with the nation's cultural values. For example, the 
case of an elementary school student who raped his friend is an example of behavior that is imitated from impressions on the internet. More ironically, parents are more proud of their children getting high grades in class than having commendable behavior.

School institutions tend to be shackled for the growth and development of children. This happens because, in the learning process, the teacher only accumulates knowledge, without giving students the opportunity to think critically and build creativity. As a result, children become less intelligent. Teachers also tend not to be good role models for their students, because there are still many teachers who unconsciously display bad behavior in front of their students, for example throwing garbage in any place, saying dirty words, smoking, and others. Even though the teacher is a model because what the teacher does indirectly becomes knowledge and lessons that will be imitated by students, especially in elementary schools.

This knowledge will make children able to know how to be good students and have intelligence abilities, have basic movement skills and character values that are learned from the easiest level to the more difficult levels, especially in physical education, sports and health subjects.

The development of the ability of these students will be developed through the learning process. One of them is through a variety of play-based learning approaches in physical education subject groups, health sports in elementary schools with the aim of developing basic movements, motor skills, instilling character values, sportsmanship, and awareness of healthy living. To be able to achieve the above learning objectives, teachers must have the ability to teach and develop innovative learning, one of which is through a variety of play-based learning approaches.

The application of learning based on the play approach will be able to create an active, creative, and fun learning atmosphere so that children do not feel bored and bored in following the learning process. The development of variations in learning based on a play approach in the form of ball games, jumping games, throwing games combined with several basic techniques for playing sports was chosen as a game activity in a variety of learning through a play approach, this is because "the world of children is the world of play". For this reason, variations in physical education learning, health sports based on a play approach are the right variations of learning to develop basic movement skills and character values at an early age in elementary schools through various game activities.

Playing is something fun for students, by playing students do not feel tired or burdened in doing physical activities, but it becomes something fun. Carrying out the process of learning motion in physical education which is a variety of movements and skills, of course, it cannot be avoided from the use of the necessary infrastructure or sports equipment and the most essential is the form of the game.

Through the observations of researchers and preliminary studies as managers and as instructors in the Teacher Professional Education Program at the Medan State University Physical Education, Health and Recreation Study Program, from the 2018 class to the 2020 class, they found several weaknesses faced by physical education, sports, and health teachers in schools. basic, the results of feedback from community service activities with the Subject Teacher Conference. Physical education, sports, and health, in developing a variety of learning that is active, creative, and fun. One of the very basic weaknesses is the low creativity and innovation of teachers in developing learning for basic movement skills and inculcating character values with variations in learning through a play approach. Learning through a play approach, in this case, is presented in the forms of games that are in accordance with the needs of students. A phenomenon in the field so far, teachers tend to use existing forms of games such as baseball, soccer, volleyball, and basketball games, even though these games are 
technically not in accordance with the level of growth and development of elementary school children and teachers perceive children as miniature adults. As a result, the learning provided is irrelevant to the competencies to be achieved and causes learning to be monotonous and less interesting.

Seeing the problems above that are crucial in learning physical education in elementary schools, researchers are interested in developing PJOK Learning Variations to Develop Basic Movement Skills and Character Values Based on Play Approach in 4th-grade elementary school students.

\section{Theory}

\subsection{Learning Variations}

Variations can be interpreted alternately or variously. Zaenal [1] said that learning variation is a teacher activity in the context of teaching and learning process interactions aimed at overcoming student boredom, so that in teaching and learning situations, students always show perseverance, enthusiasm, and are full of participation ${ }^{1}$.

Wina [2] said that "variation is a teacher's skill to keep the learning climate interesting 2 . Not boring, so that students show enthusiasm and perseverance, are passionate, and participate actively in the steps of learning activities, the notion of variation refers to the actions and actions of the teacher, both intentional and spontaneous, which are intended to stimulate and bind students' attention during the lesson. The main purpose of the teacher is to make variations in learning activities to reduce student boredom so that their attention is focused on learning.

The purposes of variation are: 1) Increase and maintain student attention during the learning process, 2) provide opportunities for students to develop their talents and interests in new things, 3) provide opportunities for the possible functioning of student learning motivation, 4) provide opportunities for students to get a way of receiving the lessons they like, 5) fostering and forming positive attitudes of students towards teachers at school, 6) providing opportunities for students to learn according to the development of their abilities, 7) providing the possibility of individual learning opportunities, 8) providing a conducive environment for students to study.

\subsection{Approach to Play}

Playing is essentially one of the necessities of life for children ${ }^{3}$. In a child's life, playing is an exercise that is carried out so that children become adult humans who have more opportunities to practice their potential, therefore playing cannot be separated from the child's life itself. Loy, McPherson, and Kenyon in [3] define that play is a variety of activities that

\footnotetext{
${ }^{1}$ Mustakim Z. Strategi dan Metode Pembelajaran. $2^{\text {nd }}$ Edition. Pekalongan: STAIN Pekalongan Press; 2011.

${ }^{2}$ Wina S. Strategi Pembelajaran. Jakarta: Predana Media Group; 2006.

${ }^{3}$ Suharjana F. Pengembangan pembelajaran senam melalui bermain di sekolah dasar. J Pend Jasmani Indonesia. 2011; 8(1):18-23.
} 
are: 1) free, 2) separate, 3) uncertain or changing, 4) spontaneously, 5) do not consider results, 6) are regulated by regulations. and make trust ${ }^{4}$.

Why a play approach should be taken is so that the ability to move (motor) and character values of children can be developed for elementary school children in particular. In playing there are also possibilities to educate children's abilities, the stronger self-awareness can foster a sense of pleasure and can foster a sense of wanting to win. In playing there is a game, in the game, it is very important other media as a tool that supports the game, the media can stimulate students in the game.

Through games, basic movements can be developed, including non-locomotor, locomotor, and manipulative basic movements. The basic movement of jumping is included in the basic locomotor movement. Jumping motion is moving the body forward by resting on one foot and landing on both feet.

Games to develop basic jumping skills

1. Jumping Obstacle Move Ball

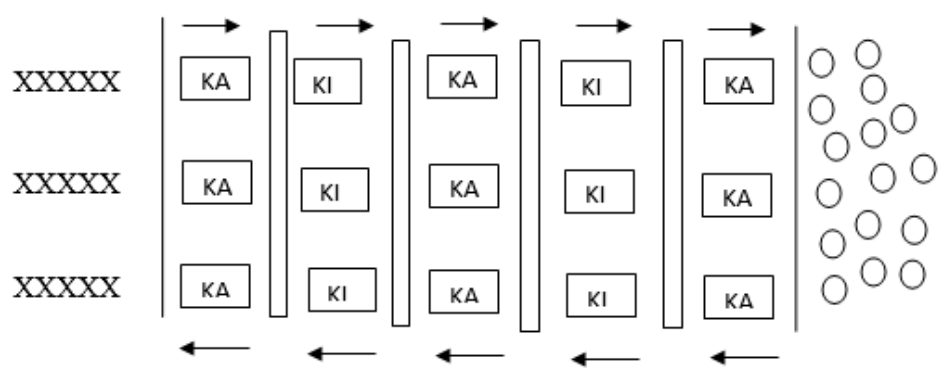

Fig. 1. Jumping Obstacle Move Ball.

Information:

KA: Focus with the right foot

KI : Focus with left foot

\footnotetext{
${ }^{4}$ Damanik S. Olahraga Rekreasi Prinsip dan Aplikasi. Medan: Unimed Press; 2014.
} 
2. Arrange Triangle Blocks

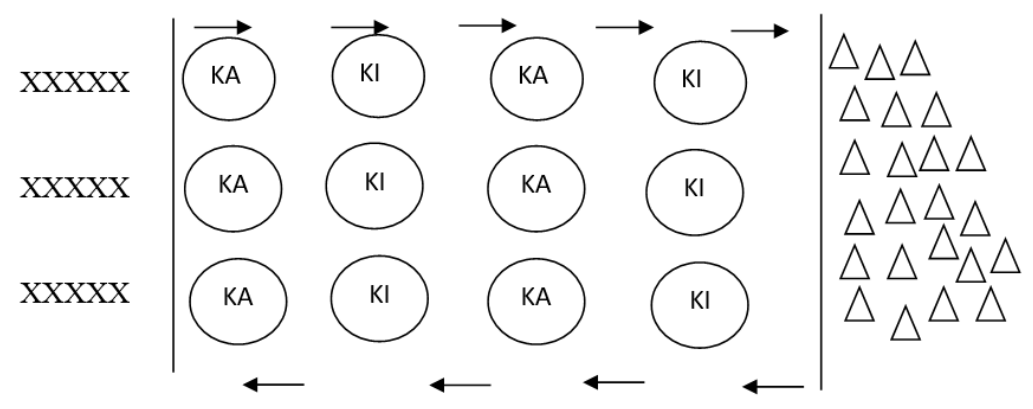

Fig. 2. Arrange Triangle Blocks.

Information:

KA: Focus with the right foot

KI : Focus with left foot

3. Putting together a Puzzle

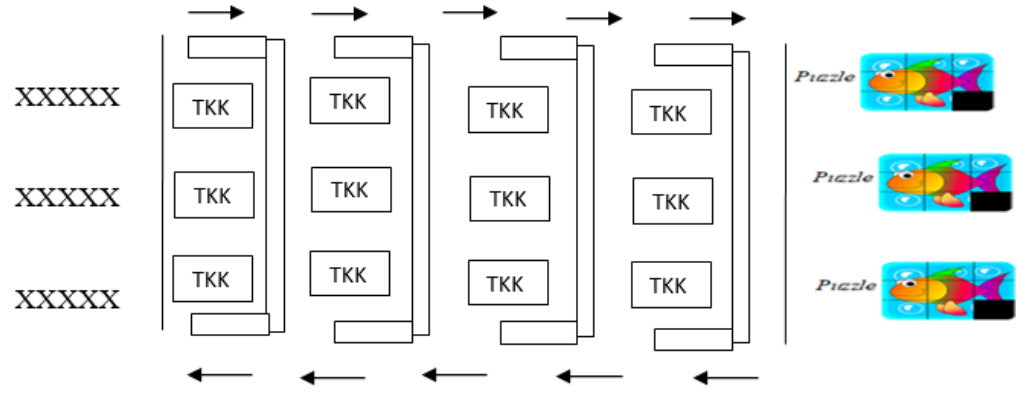

Fig. 3. Putting Together a Puzzle.

Information:

TKK : Focus on both feet

\subsection{Basic Moves Jump}

Basic motion is a change in the place or position of an object at the initial balance point such as walking, running, jumping, and throwing involving body parts such as the head, hands, and feet that can be applied in various games, sports, and physical activities ${ }^{5}$.

\footnotetext{
${ }^{5}$ Prosiding Seminar Dan Diskusi Nasional Pendidikan Dasar 2018. Tema : Menyonsong Transformasi Pendidikan Abab 21. ISSN: 2528-5564.
} 
Jumping is a movement to lift the body from one point to another that is farther or higher with a fast or slow pace of running by supporting one foot and landing with the other foot/limb in good balance ${ }^{6}$.

\subsection{Character}

Character is a unique value - both imprinted in the self and embodied (embodiment) in behavior. Character coherently radiates from the results of thought, heart, taste, and intention, as well as the sports of a person or group of people ${ }^{7}$.

The national commitment to character education is imperatively contained in Law Number 20 of 2003 concerning the National Education System. Article 3 of the Law states that "National Education functions to develop capabilities and shape the character and civilization of a dignified nation in the context of educating the nation's life, aiming at developing the potential of students to become human beings who believe and fear God Almighty and have good morals, are creative, and have good character, independent and become a democratic and responsible citizen".

Character is a way of thinking, behaving, and acting that characterizes a person who becomes a habit that is displayed in social life. Character education can be carried out simultaneously with teaching and learning activities that are integrated into every subject, including physical education and physical education. Physical education is not only a sport but also a strategic tool to build character ${ }^{8}$.

\section{Method}

The research method used in this research is research and development (Research and Development) related to product development, through the process of planning, producing, and evaluating product validity.

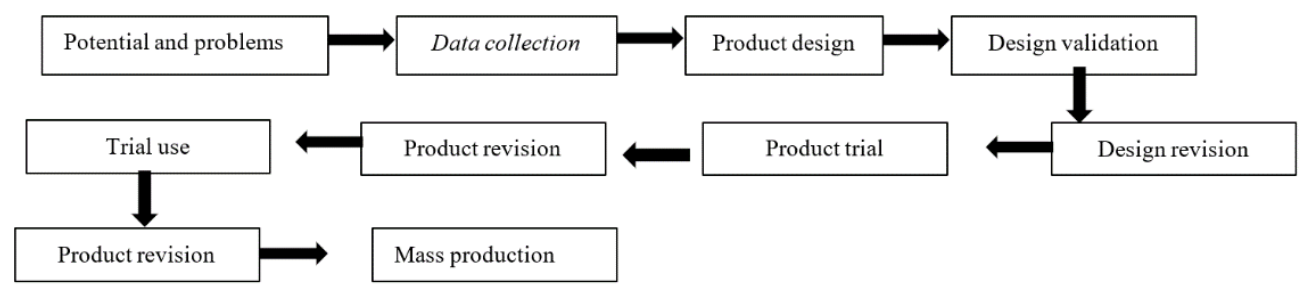

Fig. 4. Steps to Use Method Research and Development (R \& D) [4].

\footnotetext{
${ }^{6}$ Diana H. Upaya Meningkatkan Kemampuan Melompat Melalui Gerak Irama Bagi Anak Tunagrahita Sedang. J Ilmiah Pend Khusus. 2014; 1(3):128-138.

7 Kemendiknas. Pengembangan Pendidikan Budaya dan Karakter Bangsa. Jakarta: Kementrian Pendidikan Nasional; 2010.

8 Susilawati KI. Pengembangan Model Pembelajaran Karakter Pada Pendidikan Jasmani Melalui Aktivitas Permainan Pada Siswasekolah Dasar Di Kabupaten Melawi. J Pend Jasmani Kesehatan dan Rekreasi (Penjaskesrek). 2019; 6(1):14-26.
} 


\section{Results and Discussion}

Based on the results of the validation of the experts, there were several inputs in the form of suggestions and comments on the products developed (variations of learning physical education, sports, and health with a play approach to develop basic movements and character of 4th-grade elementary school students. Suggestions and comments from experts are as follows:

a). The obstacle jump game moves the ball, namely: (1) the rules in the obstacle jump game moving the ball are simplified so that children in grade 4 elementary school are easy to understand, (2) the obstacle jump game moves the ball adapted to basic competencies in learning material in grade 4 elementary school (3) the distance between the pedestals should not be too far, adjust to the child's character, (4) the equipment should be adjusted to the characteristics of children in grade 4 elementary school in the hopping game of moving the ball, and the equipment made by yourself needs to be considered for safety not only considering learning media. However, the equipment used should be cheap and practical.

b). Arranging triangular blocks, namely: (1) the rules for arranging triangular blocks are simplified so that children in grade 4 elementary school are easy to understand, (2) the game of arranging triangle blocks is adjusted to the basic competencies in learning material in grade 4 elementary school (3) the distance between the pedestal should not be too far away, adjust to the child's character, (4) the distance between the group of friends and the group of opponents in compiling the triangular block is added by 1 meter. (5) the equipment is adjusted to the characteristics of children in grade 4 elementary school, in this case, the blocks arranged are reduced again, and the equipment made by yourself needs to be considered for safety, not only considering learning media but the equipment used should be cheap and practical.

c). Putting together puzzles are: (1) the rules for compiling puzzles are simplified so that children in grade 4 elementary school are easy to understand, (2) the game of compiling puzzles is adjusted to the basic competencies in learning material in grade 4 elementary school (3) the distance between the pedestals should not be too high. far, the height of the obstacle is adjusted to the child's character, (4) the distance between the group of friends and the group of opponents in compiling puzzles is added by 1 meter. (5) the equipment is adjusted to the characteristics of children in grade 4 elementary school, in this case, the equipment made by yourself needs to be considered for safety, not only considering learning media, but the equipment used should be cheap and practical.

From the results of the discussion, for variations in learning physical education, sports, and health with the approach of playing hurdles, moving the ball, arranging triangular blocks, compiling puzzles, equipment, or learning media facilities, the researcher said that this tool is very good in terms of safety, can develop basic jump movements for 4th-grade elementary school students.

Based on the suggestions and comments of the experts as described above, it is possible to immediately revise the design of learning variations in physical education, sports, and health with the approach of playing hurdles, moving the ball, arranging triangular blocks, compiling puzzles to develop basic jump movements and character in students grade 4 elementary school. The suggestions from the experts are as follows:

1) The rules in the hurdles of moving the ball, arranging triangular blocks, compiling puzzles are simplified, there are no penalties for students who make mistakes on the footstool, students who make mistakes will no longer return to the starting line. 2) Obstacles are adjusted to the child's height, and the blocks are reduced in size and weight. 3) The length of the game time becomes 2 minutes each game and a break of 5 minutes. 4) Equipment and facilities in 
obstacle course moving the ball, arranging triangular blocks, compiling puzzles that have been made have been considered for safety. 5) The obstacle jump game of moving the ball, arranging triangle blocks, compiling puzzles has been adapted to the themes and core competencies contained in the curriculum, so that the obstacle jump game of moving the ball, arranging triangle blocks, compiling puzzles can be used by teachers of physical education, sports, health in 4th grade elementary school in applying learning variations of physical education, sports, and health on basic jumping motion material.

\subsection{Product Trial}

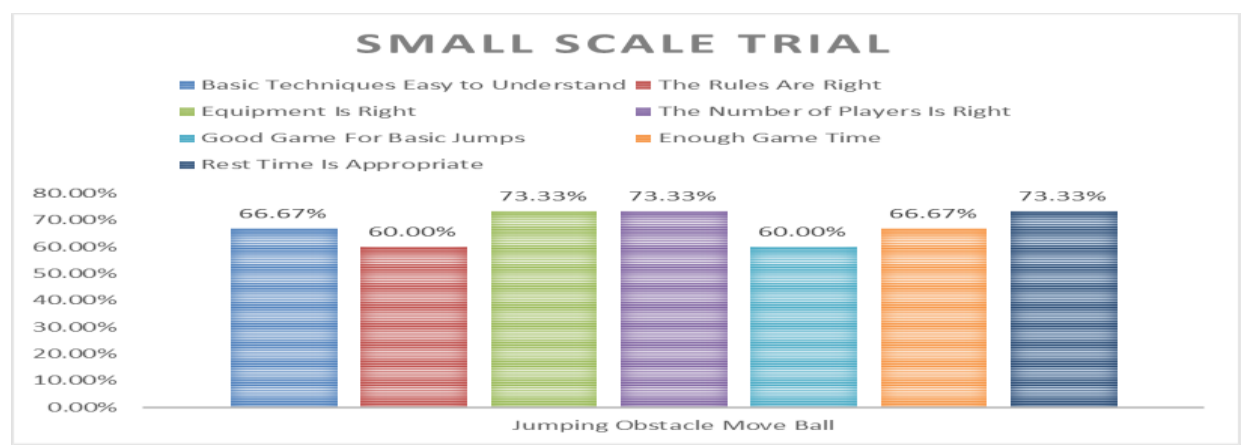

Fig. 5. Small Scale Product Trial.

From the small group test that has been carried out on 15 students, it can be concluded, $66.67 \%$ of the basic techniques (specific motion) of obstacle jump moving the ball is easy to understand and easy to play, $60 \%$ think that the rules of the obstacle jump game move the ball are correct, $73.33 \%$ of the equipment is correct jumping game to move the ball, $73.33 \%$ stated that the number of players was correct, $60 \%$ of the game was good for basic jumping movements for 4th grade elementary school students, $66.67 \%$ stated that the time given in the game was sufficient, $73.33 \%$ stated that the rest time was appropriate.

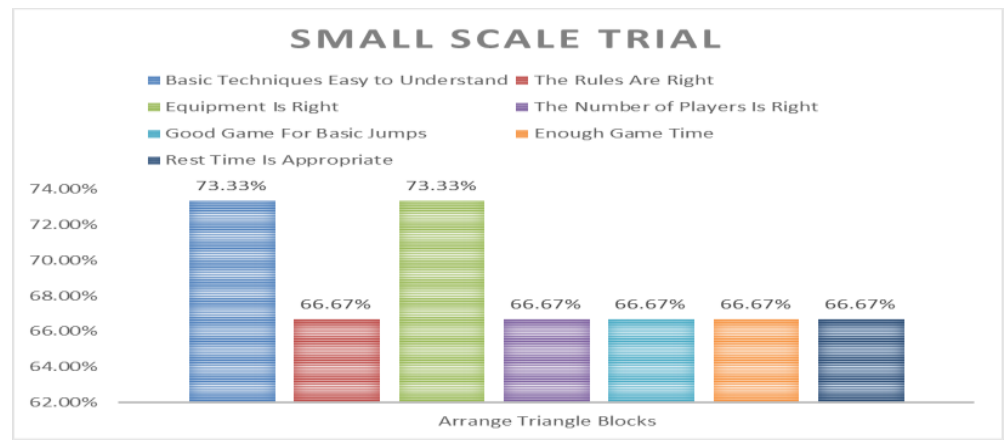

Fig. 6. Small Scale Product Trial.

From the small group test that has been carried out on 15 students, it can be concluded that $73.33 \%$ of the basic techniques (specific movements) in arranging triangular blocks are easy to understand and easy to play, $66.67 \%$ think that the game rules for arranging triangle 
blocks are correct, $73.33 \%$ of the equipment is correct, $66.67 \%$ stated that the number of players was correct, $66.67 \%$ said the game was good for basic jumping movements for 4 thgrade elementary school students, $66.67 \%$ stated that the time given in the game was sufficient, $73.33 \%$ stated that the break time was appropriate.

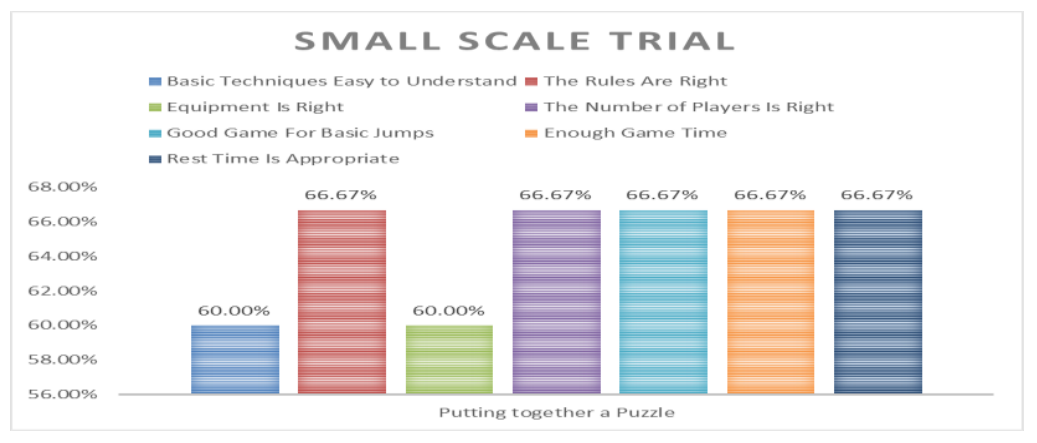

Fig. 7. Small Scale Product Trial.

From the small group test that has been carried out on 15 students, it can be concluded that $60 \%$ of the basic techniques (specific movements) in compiling puzzles are easy to understand and easy to play, $66.67 \%$ think that the rules of the game of arranging triangle blocks are correct, $60 \%$ of the equipment is correct in the game of arranging puzzle blocks, $66.67 \%$ stated that the number of players was correct, $66.67 \%$ said the game was good for basic jumping movements for 4th-grade elementary school students, $66.67 \%$ stated that the time given in the game was sufficient, $66.67 \%$ stated that the break time was appropriate.

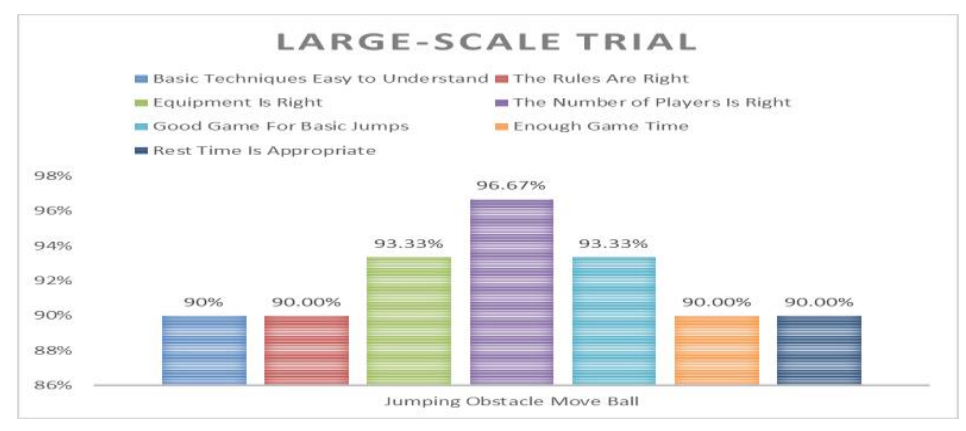

Fig. 8. Large Scale Product Trial.

From the large group test that has been carried out on 30 students, it can be concluded, $90 \%$ of the basic techniques (specific motion) of obstacle jump moving the ball are easy to understand and easy to play, $90 \%$ think that the rules of the obstacle jump game move the ball are correct, $93.33 \%$ of the equipment is correct jumping game obstacles to move the ball, $96.67 \%$ stated that the number of players was correct, $93.33 \%$ of the game was good for a basic jumping motion for 4th-grade elementary school students, $90.00 \%$ stated that the time given in the game was sufficient, $90 \%$ stated that the break time was appropriate. 


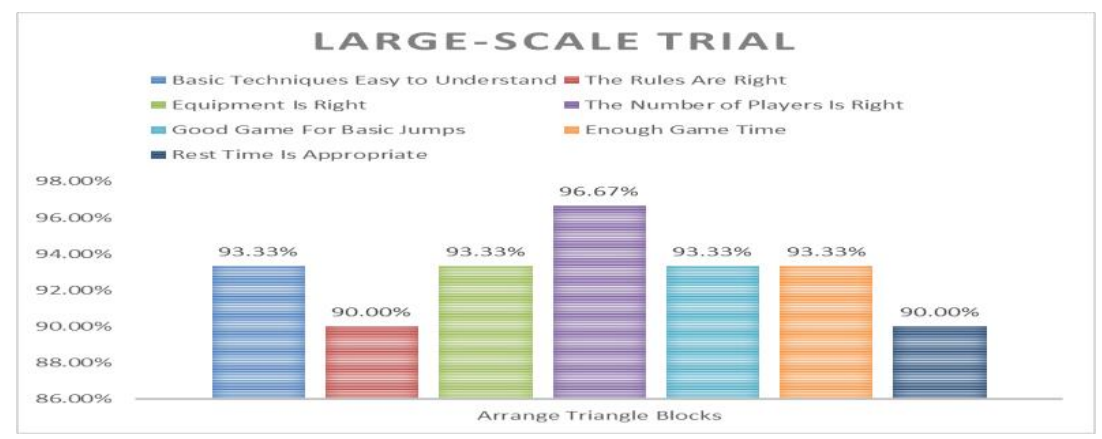

Fig. 9. Large Scale Product Trial.

From the large group test that has been carried out on 30 students, it can be concluded that $93.33 \%$ of the basic techniques (specific movements) in arranging triangular blocks are easy to understand and easy to play, $90 \%$ think that the game rules for arranging triangle blocks are correct, $93.33 \%$ of the equipment is correct, $96.67 \%$ stated that the number of players was correct, $93.33 \%$ of the game was good for basic jumping movements for 4th-grade elementary school students, $93.33 \%$ stated that the time given in the game was sufficient, $90 \%$ stated that the break time was appropriate.

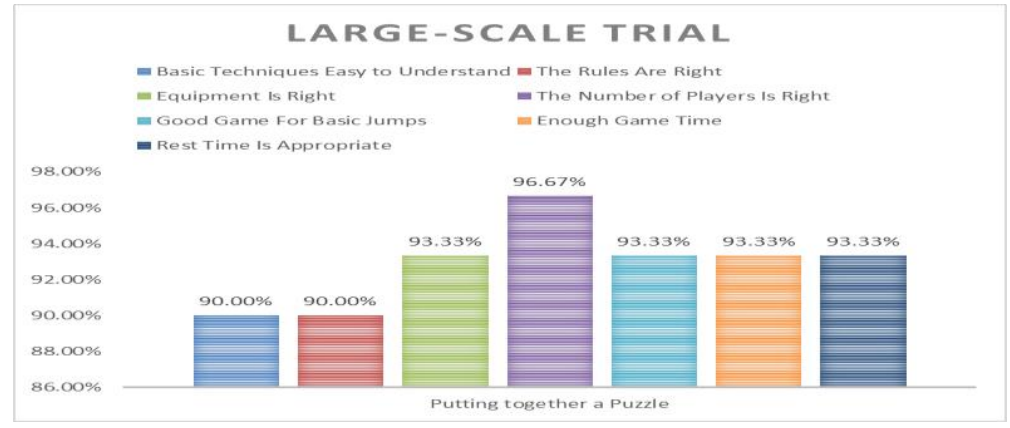

Fig. 10. Large Scale Product Trial.

From the large group test that has been carried out on 30 students, it can be concluded, $90 \%$ of the basic techniques (specific movements) in compiling puzzles are easy to understand and easy to play, $90 \%$ think that the rules of the game of arranging triangle blocks are correct, $93.33 \%$ of the equipment is correct in the game of arranging puzzle blocks, $96.67 \%$ stated that the number of players was correct, $93.33 \%$ of the game was good for basic jumping movements for 4th-grade elementary school students, $93.33 \%$ said that the time given in the game was sufficient, $93.33 \%$ stated that the break time was appropriate.

\subsection{Discussion}

Based on the results of previous studies through the application of the climbing monkey playing method in this classroom action research, it was found that there was an increase in student activity in locomotor movements by $70 \%$, non-locomotor movements by $54 \%$, and 
manipulative movements by $83.3 \%$. Based on Selvi Atesya's research results, The model for developing basic throw through this game is proven to be feasible, of quality, then acceptable for developing the conceptual skills of game motion and increasing the physical fitness of primary school students, because respondents when playing ball show that the average category is quite good, meaning that this development model is average - can be demonstrated 9 .

Based on the results of the study that for equipment or facilities for learning variations in physical education, health sports with an approach to playing hurdles, moving the ball, arranging triangular blocks, compiling puzzles, the researcher said that this tool is very good in terms of safety, can develop basic jumping movements and children's character in grade 4 elementary school. The rules in the jump ball game, move the ball, arrange triangular blocks, compose puzzles are very simple and easy to understand by children in grade 4 elementary school.

The obstacle jump game moves the ball, arranges triangular blocks, composes puzzles also in accordance with variations in physical education learning, health sports to develop basic movements and characters with a play approach and in accordance with the characteristics of elementary school children so that this product can be a variation of teacher learning in carrying out the learning process for basic jumping motion material in grade 4 elementary school. The distance of the jump can be near and far according to the jump of children in grade 4 elementary school in the game. The duration of the game is adjusted to the abilities and characteristics of children in grade 4 elementary school.

The equipment and movements used are considered for safety and not only considering variations in learning, but the equipment used is cheap and practical to use.

From the development of variations in learning physical education, sports, and health based on the play approach, the assessment of experts and teachers as practitioners in the field stated that variations in learning physical education, sports, and health based on a play approach were very well structured and suitable for use in learning to develop character values. , cooperation, courage, and honesty. The variations of learning physical education, sports, and health based on a play approach are playing hopping, moving the ball, arranging triangle blocks, compiling puzzles.

From the results of previous research by Yuni Astuti and Ali Mardius [5], collaborative games have a significant influence on optimizing the character formation of students in the State Elementary School, Balai Gadang Village, Koto Tangah District, Padang City ${ }^{10}$. Based on the results of the research by Wing Prasetya Kurniawan and M.Anis Zawaw [6], the development of traditional game models as physical education learning for upper-grade elementary school children is in accordance with the objectives of building character (cooperation, honesty, self-confidence, and caring for others) ${ }^{11}$.

\footnotetext{
${ }^{9}$ Kesumawati SA, Fahritsani H, Damanik SA. Developing Learning Model Of Basic Throw In Physical And Health Education Through Games For Second Grade Students In Central Semarang District. J Physical Educ Health Recreation. 2020; 5(1):7-13.

${ }^{10}$ Astuti Y, Mardius A. Pengembangan Permainan Kolaboratif Dalam Pendidikan Jasmani Dan Olahraga Di Sekolah Dasar Untuk Optimalisasi Pembentukan Karakter. J Pend Jasmani dan Olahraga. 2017; 2(2):79-86.

11 Kurniawan WP, Zawaw MA. Pengenalan Permainan Tradisional Goteng (Gobak Sodor Dan Bentengan) Untuk Membangun Karakter Siswa Sekolah Dasar Kelas Atas. J Pembelajaran Olahraga. 2017; 3(2):128-141.
} 


\section{Conclusion}

Based on the results of research and discussion, it can be concluded that this study produces a guide to variations in learning physical education, sports and health with game modifications, tool size, number of participating players, duration, and principles so that they can be played even with limited facilities and infrastructure. Variations in learning physical education, sports and health with a play approach can be a solution for teachers in providing learning variations on the basic jump motion material. Variations of learning physical education, sports and health with the approach of playing jump and jump, moving the ball, arranging triangular blocks, compiling puzzles can increase students' insight in terms of knowledge of game forms. As well as being able to develop the basic movements of jumping and the character of elementary school students.

\section{References}

[1] Mustakim Z. Strategi dan Metode Pembelajaran. $2^{\text {nd }}$ Edition. Pekalongan: STAIN Pekalongan Press; 2011.

[2] Wina S. Strategi Pembelajaran. Jakarta: Predana Media Group; 2006.

[3] Suryadi D. Olahraga Rekreasi Prinsipdan Aplikasi. Medan: Unimed press; 2014.

[4] Sugiyono. Metode Penelitian Kombinasi (Mix Methods). Bandung: Alfabeta; 2015.

[5] Astuti Y, Mardius A. Pengembangan Permainan Kolaboratif Dalam Pendidikan Jasmani Dan Olahraga Di Sekolah Dasar Untuk Optimalisasi Pembentukan Karakter. J Pend Jasmani dan Olahraga. 2017; 2(2):79-86.

[6] Kurniawan WP, Zawaw MA. Pengenalan Permainan Tradisional Goteng (Gobak Sodor Dan Bentengan) Untuk Membangun Karakter Siswa Sekolah Dasar Kelas Atas. J Pembelajaran Olahraga. 2017; 3(2):128-141. 